\title{
Review on Feed Resources with More Emphasis on Use of Cassava and Sweet Potato Meal in Chicken Diet: Ethiopia
}

\author{
Tagesse Tadesse \\ Department of Animal Sciences, College of Agriculture and Veterinary Medicine, Jimma University, Jimma, Ethiopia \\ Email address: \\ tagessetadesse76@gmail.com

\section{To cite this article:} \\ Tagesse Tadesse. Review on Feed Resources with More Emphasis on Use of Cassava and Sweet Potato Meal in Chicken Diet: Ethiopia. \\ Animal and Veterinary Sciences. Vol. 9, No. 2, 2021, pp. 32-38. doi: 10.11648/j.avs.20210902.11
}

Received: January 12, 2021; Accepted: March 18, 2021; Published: March 30, 2021

\begin{abstract}
This review paper is aimed to focus on feed resources with more emphasis on use of cassava and sweet potato meal in Chicken diet in Ethiopia. Poultry production has significant socioeconomic roles in developing countries like Ethiopia. Households keep chickens for home consumption, selling and breeding purposes and other purposes such as social and cultural purposes. The chicken farming in Ethiopia is predominantly backyard type of farming system and it is generally disadvantaged since the poor management. According to different research results, the commonly available sources of feeds for chickens includes cereal crops and their aftermaths and household waste products or left overs. Roots and tuber crops can be incorporated in different substitution levels in chickens' diet. Sweet potato and cassava are among the root and tuber crops and can be incorporated in chickens' diet. Substitution of sweet potato in broilers diet enhances feed consumption, growth performance and edible meat characteristics of chickens. Accordingly, addition of sweet potato meal in the ration of chicken causes no any impact on edible meat quality and it may possibly substitute up to $50 \%$ maize in broiler finisher ration without detrimentally upsetting production performance of chickens. Besides, the tuber meal of sweet potato can also be incorporated up to $25 \%$ in layers ration causing no damaging result on the performance of layer chickens. The tuber of cassava will be cut up and dried up, and milled or pelletized and incorporated in chickens' diet and it can also be included in broilers diet and capable of substituting 50\% maize in broilers ration with no adverse effect on their performances and addition of $40 \%$ cassava flour or addition of $20 \%$ cassava peel meal in layer's ration is pleasing for laying performance of chickens.
\end{abstract}

Keywords: Cassava, Chicken, Ethiopia, Feed Resources, Sweet Potato

\section{Introduction}

The main challenges for livestock production in tropics and sub-tropical countries are an inadequate feed sources and low quality of existing feed resources [18]. In Ethiopia, nutritional issues are the obligatory problems to supporting livestock production. Through the second part of the waterless period, livestock feedstuff is usually in small quantity and low quality. Regardless of livestock support to the economy and small households' livelihood, its rearing system is not satisfactorily market based and livestock production and productivity remains inefficient because of a number of limitations including insufficient diet and disease occurrence. These challenges are caused by inadequacies in the inputs like feed, genetic makeup of the animal and veterinary services and production (livestock and livestock products) marketing, including low infrastructure, absence of marketing support facilities and inadequate market evidence [11].

Poultry includes chickens, turkeys, ducks, geese, ostrich, guinea fowl, doves, and pigeons, which are all domestic fowls raised for the purpose of providing meat and eggs for human consumption. Ducks, doves, guinea fowl, ostriches, and pigeons can be found in their natural habitats in Ethiopia, while geese and turkeys are uncommon. Therefore, poultry production is similar with chicken production in the present Ethiopian situations [65]. In Ethiopia, chickens are the most common, with nearly every rural family keeping them as a valuable source of protein and income [69]. In Ethiopia, backyard chicken production systems are basic element of the farming system of just about approximately $99 \%$ of the chicken production system is composed of rural families [69] and account for more than $90 \%$ of the country's chicken and egg production [51]. Similarly, Ethiopian families raise birds 
for personal use, sale, breeding, and other purposes, including social and cultural roles [69].

Production of chicken is an essential share of livestock rearing system playing a significant socio-economic role in developing countries [6, 40]. The leading limitations of chicken production in Ethiopia include insufficient feed resources in terms of quality and quantity and high price of the feed ingredients irrespective of the system of production and geographic location. The rural chicken can obtain feed by searching in and around smallholdings, which consists of household wastes, anything edible found in the immediate vicinity, and a small amount of cereal crop supplements given by the owner [43]. Feed related concerns are the most important ones amongst these constraints. A serious problem in Ethiopia's livestock production system has been identified as a lack of feed, both in quantity and quality [1].

Most of the developing countries have been fighting to provide adequate feed to their livestock, because of inadequate production of conventional ingredients for livestock feeding. The inadequate quantities of concentrated feedstuffs they produce annually are competed for by humans and livestock. So the scarcity of feed resources often imposes a major challenge in livestock production in these countries [8]. This challenge can be eased by the use of unconventional feedstuffs in animal feeding. In this regard, various alternative feed ingredients such as cassava root meal [67, 68] sweet potato meal $[3,10,42,13,50]$ have been studied and reported to be used in animal feeding.

Despite the fact that there are few research information or findings conducted on use of cassava and sweet potato meal in chickens diet in Ethiopia, there is no a well-documented information or report. Accordingly, these results or reports need to be gathered in an understandable manner which may be used as an input for different researchers, smallholder farmers and other participants involving in chicken production and development actions. Therefore, the objective of this review paper is to assess and gather information on feed resources with more emphasis on use of cassava and sweet potato meal in Chicken diet in Ethiopia.

\section{Role of Chicken Production in Ethiopia}

In developing countries like Ethiopia, animal production in general and chicken production in particular, plays a significant socioeconomic role. Chickens' ability to adapt to most parts of the world, their rapid growth rate, fast breeding rate compared to most other livestock, or the short generation span, make them a simple way to generate family income and job creation opportunities with relatively low resource investment and readily available family labor chicken is an amazing resource for chicken farming and for household use as a protein-rich source of animal food for humans when compared to other domestic animals [64].

Chickens can be produced in various managing and production systems. The chicken production systems are free range, semi-intensive, and intensive, depending on the breed of chicken, the amount of input and output, the rate of chicken mortality, the type of producer, the goal of production, the interval of broodiness, the growing rate, and the amount of chicken reared [76].

The chicken production in Ethiopia is entirely dominated by the backyard system with insufficient production of commercial broiler and layer producers concentrated in urban and peri-urban parts of the country [31]. This was supported in developing countries among the introduction of modern chicken production systems in collaboration with new breeds, better bio-security, and protective health procedures. At present, chicken is by far the major domestic livestock types globally and encompassing for more than $30 \%$ of all animal protein consumption [62]. However, accessibility of quality feed at an affordable price is an important to successful chicken productions [12].

Essentially chickens are able to play critical role as a lowcost source of animal protein source in an unindustrialized country like Ethiopia due to its short generation interval and better feed conversion effectiveness compared to other livestock [4]. Moreover, poultry meat and eggs are the best edible and simply consumable animal proteins with high essential amino acid content and biological benefits [61]. Modern broilers such as Cobb500 has been reported to be able to reach slaughter body weight gain of $1.5-2 \mathrm{~kg}$ at an age of five weeks [36] and found to be the greatest efficient meat type chicken with high feed conversion efficiency and fast growth rate [15]. Chicken are produced for various purposes in Ethiopia. According to the findings of Halima et al., [35] and Moges et al., [47] village chickens are kept in northwest Ethiopia for a variety of purposes, the first of which is to sell for cash. Poultry farming, in addition to its cheaper means of creating rural employment in Ethiopia, play a substantial role in the socio-cultural (as gifts, special dishes for respected guests) and religious lives of the people, largely in the rural community [26]. Poultry production promises considerable potential to advance the livelihoods of the rapidly increasing population of Ethiopia [5] due to its small investment for price of feed, space requirement, small price of the chickens, easy to sale off at times of economic difficulty [26] and relative ease of improving productivity in the rural setting [5]. In Ethiopia, chickens will be reared for different purposes. The reports of Solomon et al., [66] indicated that the purposes of poultry rearing were prioritized and identified in Metekel Zone of Ethiopia for cash income generation $(98.6 \%)$, family use $(95.2 \%)$, extra farm operation $(82.8 \%)$, job opportunity creation $(60 \%)$, use of chicken for cultural or religious rituals $(39.3 \%)$, and giving chicken as a gift (20\%). According to Moges et al., [47] the first significant feature of processing chicken in Fogera (77.8\%) and Dale was selling live chicken (43.7 percent) areas of Ethiopia.

\section{Feed Resources for Poultry in Ethiopia}

According to the findings of Dwinger et al.,[22] family 
chicken production in Africa stay alive by searching and generally no supplements given except that occasionally home waste fed to the birds and in other conditions the feed supplemented with grain. In emerging countries like Ethiopia, the whole standard of production of chickens is mainly scavenging type and usually inefficient as a result of the low level of inputs and additionally there are a considerable types of problems to village chicken production [20]. Family chicken production is a suitable system that makes the best exploitation of nearby accessible resources [48].

The findings of Tion and Adeka [71] revealed that crops grown and their by-products have been used as a potential feed sources for smallholder chicken producing farmers and the main crops produced by smallholder farmers were maize, Ensete ventricosum /enset, Coffee, haricot bean, sweet potato, potato, tomato, linseed and cabbage. Because of its high energy, low fiber content, better edibility, and presence of pigments and essential fatty acids, maize grain is an ideal carbohydrate source for chicken diet preparation [58]. Various cereal crops, wheat and maize, mixture of wheat, maize and sorghum, and mixture of sorghum and maize [35]; maize, wheat, rice and maize together [38] wheat and maize grains in central and western highlands of Ethiopia were described as supplementary feed sources.

Along with the above cereal crops, farmers also supplement food leftover in the house including "Kocho" or baked enset [38]; kitchen wastes and bone meal [21]; home waste products [59]; bread, injera, cover of tomatoes, carrot, potatoes, vegetables and cooked foods [75]; insects, grass and harvest leftovers [70]; worms, insects, grass, vegetables, and kitchen wastes eastern Ethiopia [30]; cereal debris, kitchen left overs, "kocho" as reported by Bekele [14]; and weeds leaf, various cereals leaf, various fruit leafs, enset leaf, cabbage [38]; enset (Ensete ventricosum) and cabbage [44]; green grasses [21]; supplementary feeds [34] and home leftovers [75] in different parts of Ethiopia. Therefore, the smallholder chicken production goes environmentally suitable as they change insects and home leftovers to an important cheap and quality animal protein source of food to the households.

A root is a compact, often enlarged storage organ having hairy stems that develops from root tissue. A tuber is also a root. It's most likely an enlarged storage organ, but it grows from a rhizome, or extended stem tissue. So, while a tuber is a root crop, a plant may also be a root. Carrots and cassava, for example, are root vegetables, while potatoes, sweet potatoes, and yams are edible tubers. There are dissimilarities in the way edible root crops or plants grow and the way edible tubers grow. Since root vegetables and edible tubers are the parts of the plant that power the plant's above-ground growth, they contain a lot of starchy nutrients. Root and tuber vegetables are the parts of the plant that grow below the soil or on the soil surface, while most vegetables grow above ground. Tubers are formed by underground rhizomes that can run horizontally just beneath the soil surface or parallel to it. The tuber is just a swollen section of one of these rhizomes. These swollen chunks may be used to gather nutrients. Their goal is to store nutrients for the plants so that they can produce healthy new growth in the spring [29].

\subsection{Use of Sweet Potato (Ipomoea Batatas (L.) Lam) Meal in Poultry Diet}

Above $80 \%$ of the sweet potato produced in sub Saharan African countries is consumed fresh by human beings. The residual part is either processed for starch or used for animal feed. The tubers are mostly made up of starch and soluble carbohydrates, but the leaves and vines are rich in amino acids, minerals, and vitamins. Raw sweet potato starch and protein digestibility has been cited as a barrier to their increased use as livestock feed [19]. Sweet potatoes might be used on-farm or as an ingredient in commercial compound livestock feeds [32]. Addition of sweet potato root meal in broiler chicken diet at $0,10,20$ and $30 \%$ had no adverse impact on the average daily intake and feed conversion ratio of chickens [13].

Addition of sweet potato meal in the diets of chicken had no effect on carcass quality of broilers at eight weeks of age and it can be substituted in broiler finisher diet at 50\% maize substitution without harmfully disturbing efficiency of chickens [42]. According to the finding of Agwunobi [2] higher inclusion level of sweet potato meal utilization on broiler diet led to poor efficiency of feed and high feed conversion ratio and consequently resulted in higher feed price per $\mathrm{Kg}$ body weight gain of chickens. These authors recommended that sweet potato meal on broiler diet should not exceed 20\% substitution level if substituted for maize. The results of Shoremin and Job [63] indicated that sweet potato meal at $45 \%$ inclusion level can securely substitute maize in pullet mash. Chicken fed rations encompassing of 0 to $50 \%$ sweet potato root meal and found that there was increased body weight gain up to $40 \%$ inclusion though there was a significant decrease at the $50 \%$ level of replacement [10].

The orange-fleshed sweet potato tuber meal can be used up to $25 \%$ in the ration of laying hens without losing egg quality as revealed by Okereke et al., [53]. The findings of Onyekwere et al., [57] revealed that adding $20 \%$ of sweet potato root meal to the diet had no negative impact on broiler starter phase. Similarly, inclusion of $38.73 \%$ dietary sweet potato meal will enhance acceptable growth performance for Japanese quail [25]. Sweet potato has a high digestibility and soluble carbohydrate material. It has low fiber content and is mostly made up of starch, which accounts for 4-7\% sugar content. Furthermore, high reducing sugar content in sweet potato tuber and flour causes diarrhea at higher levels of inclusion, indicating that sweet potato meal inclusion rates in livestock feeds should be limited. According to other experiments, with providing $25 \%$ potato to starter chickens [50] and 50\% sweet potato to broiler starter [9] revealed that either potato or sweet potato in rations caused no bad impact on the performances of chickens. The ability of sweet potato dried leaves to provide enough energy and protein for optimal growth and feed conversion efficiency when used in finisher chicks diets up to a level of $10-15 \%$ of the diet in chickens ration, which led to an improved weight gain than 
the category that was not supplemented with sweet potato dried leaves and suggested $10 \%$ sweet potato as optimum level of utilization by broiler chickens was revealed in their experiment [73]. The experiment conducted by Mosebework et al.,[49] indicated that substitution of orange fleshed sweet potato tuber meal for maize by $12 \%$ and $16 \%$ at starter and $15 \%$ and $20 \%$ levels at grower phases have enhanced feed intake, body weight gain and carcass characteristics of chickens. Taking into account the high cost of soybean seed, an experiment was conducted on partially replacing cooked soybean seed with sweet potato leaf meal in broiler diets and stated that sweet potato leaf meal can be a viable alternative in smallholder chicken production systems [45].

\subsection{Use of Cassava (Manihot Esculenta Crantz) Meal in Poultry Diet}

Cassava (Manihot esculenta Crantz) is a shrub grown in the tropical and subtropical countries for its underground starchy tuberous roots. Cassava roots also called cassava tubers are a main primary food for more than 800 million people in the world [23]. Cassava roots are high in energy since they are mostly made up of starch and soluble carbohydrates, but they are low in protein. More than $60 \%$ of all cassava produced in Africa is expected to be eaten, with about a third of the harvest going to animals and the rest being converted into secondary products [61].

The findings of Kuiper et al., [39] indicated that cassava tubers can be consumed boiled, mashed, deep-fried, etc. and there are many food products based on cassava such as tapioca (cassava starch), a worldwide food ingredient, fufu (cassava flour boiled in water) and garri (fermented cassava mash), the two last popular foods in West and Central Africa. The chips and pellets of cassava are the essential cassava products recycled in animal feeding and can replace some or all of the cereal grain in poultry rations [37].

Other cassava products include the finger-like leaves, which are eaten as vegetables or used as animal feed, as well as various by-products from the cassava processing industries, such as pomace and peels from starch, ethanol, and cassava food production, which can be used as livestock feed. Animal feed is made from cassava flour which is unsafe for human consumption [17]. More than a third of cassava production is used for animal feeding [28]. Cassava tubers are sliced and dried before being powdered or pelletized for use in industrial animal feed. The methods used at different scales of chip and pellet production are related and cassava chips can be formed by simple techniques in the household or village as well as on a large mechanized scale. The choice of a technology is determined by the amount of cassava to be processed, the availability of capital and labor cost as well as the availability of comparatively cheap energy [33].

The feasibility of using cassava meal as a maize substitute in poultry feed is largely dependent on the availability of an excellent source of protein and the inclusion of sufficient methionine in the ration to satisfy both body requirements and cyanide detoxification [54]. The findings of Tekalegn et al.,[71] also revealed the advantageous effect of incorporating cassava root meal to substitute up to $30 \%$ maize in a broiler ration while attempts are done to decrease the dirtiness through the adding of oil and supplementation with adequate levels of methionine and lysine amino acids. Cassava root meal is capable of fully substituting maize in layers ration [7]. Broiler chickens fed ration comprising cassava pellets had improved feed consumption compared to birds fed rations with cassava chips or maize [16]. The reports of Edache et al., [24] indicated that 35\% cassava meal based ration is suggested for growing Japanase quail. Cockerel starter birds could tolerate only about $28 \%$ level of cassava sievate in their ration [52]. The findings of Onwujiariri et al., [56] revealed that wet maize milling waste and cassava root sievate can effectively substitute maize up to $35 \%$ without affecting growth performance and feed utilization of finisher broilers.

Most of the studies show that substitution of cassava in chickens' diet causes attractive responses in performances of chickens. For example, mixture of cassava root meal and leaves in ratio $4: 1$ could substitute maize in poultry diet and reduce price of feed without a decline in weight gain or egg production of the layers [74]. Feeding cassava chips supplemented with Moringa oleifera leaf meal at 5 and $10 \%$ levels indicated that cassava chips substituting maize at $55.56 \%$ and $83.33 \%$ in the diets of broilers has no adverse effect on productivity and blood parameters when 5\% Moringa oleifera leaf meal was incorporated in diet [55].

There is limited experiment conducted in Ethiopia in utilizing cassava in poultry diet. For example, depending on dry matter consumption and growth performance of broilers, cassava root chips can totally substitute maize grain in broiler rations as energy feed source as revealed by Etalem et al., [27]. Conversely, based on the results of yields of main edible meat parameters, cassava root chips could replace maize grain less than $50 \%$ level of substitution in broilers diet and $50 \%$ cassava root chips or $5 \%$ moringa olifera meal or a mixture of both can effectively be used in the ration of layers substituting maize grain and soybean meal. The final body weight gain, total body weight gain and daily body weight gain of broiler chickens were improved by substitution of Noug seed cake with cassava leaf meal at $4 \%$ substitution level. Accordingly, cassava leaves will be a good protein source to substitute the expensive Noug seed cake in the broiler diet [46].

\section{Conclusion}

Chicken productions play significant socioeconomic roles in developing countries like Ethiopia. Ethiopia has a variety of poultry feed resources. The farming system of chickens is mainly scavenging type and it is commonly low due to the low level of inputs. Cereal crops and their by-products can be used as a potential source of feed for chickens. Cassava and sweet potato and are among the root and tuber crops and can be incorporated in chickens' diet. Accordingly, meal of sweet potato can be included in broiler ration up to $50 \%$ maize grain substitution without detrimentally upsetting production 
performance of chickens. Besides, sweet potato tuber meal can also be added up to $25 \%$ in ration of laying hens causing no impact on quality parameters of eggs. The tuber of cassava could be included in broilers diet and substitute up to $50 \%$ maize in the ration without harming the performances of both broiler and layer chickens. In conclusion, sweet potato and cassava can be included in chickens' diet without upsetting the performances of chickens.

\section{References}

[1] Adunga Tolera. 2009. Livestock feed supply situation in Ethiopia. In: Proceedings of the $16^{\text {th }}$ Annual Conference of the Ethiopian Society of Animal Production (ESAP) on Commercialization of Livestock Agriculture, Addis Ababa, Part I, Ethiopia; p. 21-38.

[2] Afolayan S. B., Dafwang I. I., Tegbe T. S. B, and Sekoni A. 2012. Response of Broiler Chickens fed on maize based diets substituted with graded level sweet potato meal. Asian Journal of Poultry Science, SSN, 18193609/DOI:10.3923/ajpsaj.2012.

[3] Agwunobi LN. 1999. Performance of broiler chickens fed sweet potato meal (Ipomea batatas L.) diets. Trop Anim Health Prod.; 31: 383-9.

[4] Ahmad, S., Mehmood, S., Javed, K., Mahmud, A., Usman, M., Rehman, A., Ishaq, H. M., Hussain, J. and Ghayas, A., 2018. Different Selection Strategies for the Improvement of the Growth Performance and Carcass Traits of Japanese Quails. Brazilian Journal of Poultry Science, 20 (3), pp. 497-506.

[5] Alemu Yami, 1995. Poultry Production in Ethiopia. Journal of World Poultry Science, 51: 197-201.

[6] Alders R 2004. Poultry for profit and pleasure. FAO diversification Booklet 3. FAO (Food and Agriculture Organizations of the United Nations), Rome, Italy.

[7] Akinola LAF, Oruwari BM. 2007. Response of laying hens total dietary replacement of maize with cassava. Nig. J. Anim prod. 34: 2: 196-202.

[8] Aregheore, E. M., 2000. Chemical composition and nutritive value of some tropical by-product feedstuffs for small ruminants - in vivo and in vitro digestibility. Anim. Feed Sci. Technol., 85 (1-2): 99-109.

[9] Ayuk E A, 2004: Effects of sweet potato meal on the growth rate of broilers. Livestock Research for Rural Development. Vol. 16, Art. \#73. Retrieved on November 2, 2020, from http://www.lrrd.org/lrrd16/9/ayuk16073.htm

[10] Ayuk, E. A., and A. Essien. 2009. Growth and haematological re-sponse of broiler chicks fed graded levels of sweet potato (Ipo-moea batata) meal as replacement for maize. Int. J. Poult. Sci. 8: 485-488.

[11] Azage Tegegne, Hussen K, and Kurtu MY. 2008. Traditional cow and camel milk production and marketing in agropastoral and mixed crop-livestock systems: The case of Mieso district, Oromiya Regional State, Ethiopia. Project working paper 13, Nairobi, Kenya: Improving Productivity and Market Success (IPMS) of Ethiopian Farmers; 2008. p. 1-58.

[12] Basak, B., Pramanik, M. A. H, Rahman, M. S., Tarafdar, S. U. and Roy, B. C., 2002. Azolla (Azolla pinnata) as a feed ingredient in broiler ration. Int. J. Poultry Sci, 1 (1), pp. 29-34.

[13] Beckford, R. C., Bartlett, J. R., 2015. Inclusion levels of sweet potato root meal in the diet of broilers I. Effect on performance, organ weights, and carcass quality. Poult. Sci. 94, 1316-1322.

[14] Bekele B. 2016. Assessment of Locally Available Poultry Feeds, Feeding Practices and Health in Sidama Zone and Halaba Special Woreda in SNNPR. Journal of Biology, Agriculture and Healthcare. Vol. 6, No. 7, 2016.

[15] Bergsma, N. J., Fischer, A. R., Van Asselt, E. D., Zwietering, M. H. and De Jong, A. E., 2007. Consumer food preparation and its implication for survival of Campylobacter jejuni on chicken. British Food Journal, 109 (7), pp. 548-561.

[16] Bhuiyan MM, and Iji PA. 2015. Energy Value of Cassava Products in Broiler Chicken Diets with or without Enzyme Supplementation. Asian-Australas J Anim Sci. 2015; 28 (9): 1317-1326.

[17] Boscolo, W. R.; Hayashi, C.; Meurer, F., 2002. Apparent digestibility of the energy and nutrients of conventional and alternative foods for Nile tilapia (Oreochromis niloticus). Rev. Bras. Zootec., 31 (2): 539-545.

[18] Boufennara, Lopez, S., Bousseboua, H., Bodas, R. and Bouazza, L. 2012. Chemical composition and digestibility of some browse plant species collected from Algerian arid rangelands. Spanish Journal of Agricultural Research. 2012. 10 (1): 88-98.

[19] Collins, W. W., 1997. Root Vegetables: New Uses for Old Crops, p. 533-537. In: J. Janick and J. E. Simon (eds.), New crops. Wiley, New York.

[20] Dessie T and Ogle B. 2001. Village poultry production systems in the central highlands of Ethiopia. Trop Anim Health Prod. Dec; 33 (6): 521-37.

[21] Dessie, T., W. Esatu, L. V. Waaij, F. Zegeye, S. Gizaw, O. Mwai and J. van Arendonk, 2013. Village chicken production in the central and western highlands of Ethiopia: Characteristics and strategies for improvement. Nairobi, Kenya: International Livestock Research Institute.

[22] Dwinger, R. H, Bell, J. G. and Permin, A. 2003. A program to improve family poultry production in Africa. B. P. 6268, Rabat-Institutes, Morocco.

[23] Ecocrop, 2011. Ecocrop database. FAO.

[24] Edache JA, Musa U, Karsin PD, Esilonu DO, Yisa A, Okpala EJ, Zwander NJ. 2007. The feeding value of cassava meal diets for growing Japanese quail (Coturnix coturnix japonica) Nig. J. Anim prod.; 34 (1) 77-82.

[25] Edache JA, Musa U, Ehizokale MUM, Esilonu JO, Okpala EJ, Karsin PD, Yisa A, Zwandor NJ. 2009. Replacement value of sweet potato (lpomea Batatas) meal for maize in practical diets fed to quail (Cotumix cotumix japonica) chicks. Nig J. Anim Prod.; 36: 11: 34-40.

[26] ESAP (Ethiopian Society of Animal Production), 2008. Commercalization of livestock agriculture in Ethiopia. Tedelle Dessie (Eds). Proceedings of the $16^{\text {th }}$ annual conference of the Etiopian Society of Animal Production (ESAP) held in Addis Ababa, Ethiopia, October 8 to 10, 2008. Part I plenary session. ESAP, Addis Ababa, 329p. 
[27] Etalem T, Getachew A, Mengistu U and Tadelle D. 2013. Nutritional Value of Cassava Root Chips and Moringa Oleifera Leaf Meal in Broiler And Layer Rations. PhD Dissertation.

[28] FAO, 2011. FAOSTAT. Food and Agriculture Organization of the United Nations.

[29] Gardner K. 2019. The Difference between Tubers \& Root Crops https://www.gardenguides.com/13407021-thedifference-between-tubers-root-crops.html accessed on August, 2020.

[30] Getachew T, Kebede E, Ameha N, and T. Terefe A. 2015. Village Chicken Husbandry Practice, Marketing and Constraints in Eastern Ethiopia. J. World's Poult. Res. 5 (4): 104-108.

[31] Gezahegn Ayele and M. R. Karl, 2010. Poultry value chains and HPAI (Highly Pathogenic Avian Influenza) in Ethiopia. Africa/Indonesia TeamWorking Paper 25. Pp. 9-13.

[32] Gupta, J. J., Bardoloi, R. K.; Reddy, P. B.; Anubrata Das, 2009. Performance of crossbred pigs fed on raw and boiled sweet potato tuber at various levels at different stages of growth. Indian J. Anim. Sci., 79 (7): 696-699.

[33] Hahn, S. K.; Reynolds, L.; Egbunike, G. N., 1992. Cassava as livestock feed in Africa. Proc. IITA/ILCA/Univ. of Ibadan Workshop on the Potential Utilization of Cassava as Livestock Feed in Africa, 14-18 November 1988, Ibadan, Nigeria.

[34] Mogesse, H. H., 2007. Phenotypic and genetic characterization of indigenous chicken populations in Northwest Ethiopia (Doctoral dissertation, University of the Free State).

[35] Halima, H., W. C. Nasser, D. Tadelle, A. De Kock and E. Van Marle-Koster, 2007. Village-based indigenous chicken production system in north-west Ethiopia. Tropical Animal Health Production, 39: 189-197.

[36] Henn, J. D., Bockor, L., Ribeiro, A. M. L., Coldebella, A. and Kessler, A. D. M., 2014. Growth and deposition of body components of intermediate and high performance broilers. Brazilian Journal of Poultry Science, 16 (3), pp. 319-328.

[37] Iji PA, Bhuiyan MM, Chauynarong N, Barekatain MR, Widodo AP. 2011. Improving the nutritive value of alternative feed ingredients for poultry. Proceedings of the Recent Advanced in Animal Nutrition; Australia. pp. 115-122.

[38] Kibreab, Y.; Kassa, T.; Zelalem, A., 2015. Feed and feeding practice of village chicken at Kafa and Bench Maji Zone, South West Ethiopia. Europ. J. Biol. Sci., 7 (4): 203-208.

[39] Kuiper, L.; Ekmecki, B.; Hamelink, C.; Hettinga, W.; Meyer, S.; Koop, K., 2007. Bio-ethanol from cassava. Project number: PBIONL062937. Ecofys Netherlands BV, Utrecht.

[40] Kondombo SR. 2005. Improvement of village chicken production in a mixed (chicken-ram) farming system in Burikina Faso. PhD thesis submitted to Wageningen University, The Netherlands 208.

[41] Lebot, V., 2009. Tropical root and tuber crops: cassava, sweet potato, yams and aroids. Crop production science in horticulture (17), CAB books, CABI, Wallingford, UK.

[42] Maphosa T, Gunduza K T, Kusina J and Mutungamiri A 2003: Evaluation of sweet potato tuber (Ipomea batatas 1.) as a feed ingredient in broiler chicken diets. Livestock Research for
Rural Development. Volume 15, Article \#3. Retrieved August 26, 2020, from http://www.lrrd.org/lrrd15/1/maph151.htm

[43] Mehari K. 2016. Poultry production systems and its feed resources in Ethiopia: a research review. Sci. J. Ani. Sci., 5 (2): $220-227$.

[44] Mekonnen G/egziabher, 2007. Characterization of the small holder poultry production and marketing system of dale, Wonsho and Loka abaya Wered as of SNNPRS.

[45] Melesse A, Alemu T, Banerjee S and Berihun K. 2017. The effect of the partial substitution of roasted soybean seed with graded levels of sweet potato (Ipomoea batatas) leaf meal on growth performances and carcass components of broiler chickens. Asian-Australas J Anim Sci.

[46] Melesse A, Masebo M, Abebe A. 2018. The Substitution Effect of Noug Seed (Guizotia Abyssinica) Cake with Cassava Leaf (Manihot Escutulata C.) Meal on Feed Intake, Growth Performance, and Carcass Traits in Broiler Chickens. Journal of Animal Husbandry and Dairy Science Volume 2, Issue 2, 2018, PP 1-9.

[47] Moges, F., Tegegne, A. and Dessie, T. 2010. Indigenous chicken production and marketing systems in Ethiopia: Characteristics and opportunities for market-oriented development. IPMS (Improving Productivity and Market Success) of Ethiopian Farmers Project Working Paper 24. Nairobi, Kenya: ILRI. Retrived on October 28, 2020 from https://cgspace.cgiar.org/handle/10568/2685

[48] Moges, T., Mellesse, A., Dessie, T. 2010. Assessment of village chicken production system and evaluation of the productive and reproductive performance of local chicken ecotype in Bure district, North west Ethiopia. African Journal of Agricultural Research 5 (13): 1739-1748.

[49] Mosebework Kassa, Tegene Negesse, Ajebu Nurfeta. 2018. Effect of Replacing Maize (Zea Mays L.) with Orange Fleshed Sweet Potato Tuber (Ipomoea Batatas) on Performance of Cobb 500 Broiler Chickens. Agri Res \& Tech: Open Access J. 2018; 13 (5): 555895. DOI: 10.19080/ARTOAJ.2018.13.555895.

[50] Mozafari O, Ghazi S, Moeini MM. 2013. The effects of differen levels of edible potat (Solanumtubresum) replacing maize on performance, serum metabolite and immune system of broiler chicks. Iran J. Anim. Sci.; 3 (3): 583-8.

[51] Nigussie D, Van der Waaij LH, Dessie T, Van Arendonk JAM. 2010. Production objectives and Trait preferences of village poultry producers of Ethiopia: implications for designing breeding schemes utilizing indigenous chicken genetic resources. Trop. Anim. Health Prod.; 42: 1519-529.

[52] Nwokoro SO, Orheruata AM, Paul IO. 2000. Replacement of maize with cassava sievates in cockerel starter diets; some blood metabolic. Poceeding of $25^{\text {th }}$ Annual conference with NSAP. p. 234-6.

[53] Okereke CO, Oti E, Nwauzor EC. 2009. Effect of dietary inclusion of orange-fleshed sweet potato meal on egg quality of laying hens. Proceedings of 14th Annual Conference of Animal Science Association of Nigeria (ASAN). p. 382-4.

[54] Okereke CO, Ukachukwu SN. 2005. Effect Of Dietary Inclusion Of Composite Cassava Meal On Egg Production Charateristics Of Laying Hens. Student Thesis, Micheal Okpara University. Deparament of Non Ruminant Animal Nutrution And Biochemistry; 1-38. 
[55] Olugbemi T S, M utayoba S K and Lekule F P. 2010. "Effect of $\mathrm{M}$ oringa (Moringa oleifera) inclusion in cassava based diets fed to broiler chickens" International Journal of Poultry Science 9: $363-367$.

[56] Onwujiariri EB, Onyekwere MU, Okoronkwu MO, Okechukwu S. 2000. Evaluation of wet maize milling waste and cassava root sievaite as a replacement for maize in broiler finisher diets. Proc $42^{\text {nd }}$ Annual Conference, Agricultural Society of Nigeria (ASA). October 19th-23 ${ }^{\text {rd }} 2008$ Ebonyi State University Abakilike Nigeria. p. 669-71.

[57] Onyekwere MU, Iheukwumere FC, Onwujiariri EB, Okechukwu SO. 2008. Effect of sweet potato (lpomea Batatas) Root meal on the growth response and haematological value on broiler starter. Proc 42nd Annual conf Agricultural Society of Nigeria (ASN). October 19th23rd 2008 Ebonyi State University Abakalike Nigeria. p. 6013.

[58] Panda K, Zaidi PH, Rama rao SV, Raju MV. 2014. Efficacy of quality protein maize in meeting energy and essential amino acid requirements in broiler chicken production. J Appl Anim Res. 42 (2): 133-9.

[59] Samson Leta and Endalew Bekana, 2010. Survey on Village Based Chicken Production and Utilization System in Mid Rift Valley of Oromia, Ethiopia. Global Veterinaria, 5 (4): 198203.

[60] Schonfeldt, H. C. and Hall, N., 2013. "Fish, chicken, lean meat and eggs can be eaten daily": a food-based dietary guideline for South Africa. South African journal of clinical nutrition, 26 (3), pp. s66-s76.

[61] Scott, G; Best, R; Rosegrant, M. W. and Bokanga, M, 2000. Roots and Tubers in the Global Food System -A vision statement to the year 2020. CIAT-CIP-IFPRI-IITA - IPGRICIP. 45.

[62] Sebho, H. K., 2016. Exotic chicken status, production performance and constraints in Ethiopia: a review. Asian Journal of poultry science, 10 , pp. 30-39.

[63] Shoremin OIA, and Job TA. 2000. Utilization of dried sweet potato (lpomea batatas) in laying pullet diet. Proceeding of $25^{\text {th }}$ Annual Conference with NSAP.

[64] Solomon D. 2004. Growth Performance of Local and White Leghorn Chicken under Intensive Management System. J Sci 27: 161-164.

[65] Solomon D. 2007. Suitability of hay-box brooding technology to rural household poultry production system. Jimma University College of Agriculture and Veterinary Medicine, Jimma, Ethiopia.
[66] Solomon Zewdu, Binyam Kassa, Bilatu Agza, Ferede Alemu. 2013. Village chicken production systems in Metekel zone, Northwest Ethiopia. Wudpecker Journal of Agricultural Research ISSN 2315-7259. 2 (9): 256-262. Retrived on October, 28, 2020 from https://www.researchgate.net/publication/258860407_Village chicken_production_systems_in_Metekel_zone_Northwest_Et hiopia

[67] Sultana F, Khatun MF, Ali MA. 2011. Effect of dietary cassava tuber meal on egg production and egg quality of laying hen. Int J BioRes. 2: 1-4.

[68] Sultan F, Ali MA, Jahan I. 2012. Growth performance meat yield and profitability of broiler chickens fed diets incorporating cassava tuber meal. J Environ Sci Nat Resour. 5 (1): 47-53.

[69] Tadelle, D., T. Million, Alemu Yami and K. J. Peters, 2003. Village chicken production systems in Ethiopia: Use patterns \& performance valuation and chicken products \& socioeconomic functions of chicken. Livestock Research for Rural Development 15 (1).

[70] Tadelle D, and Peter KJ. 2003. Indigenous chicken in Ethiopia: neglected but worth the cost of conservation through improved utilization. Humboldt University of Berlin.

[71] Tekalegn Y., Etalem T., and Getnet A., 2017. Poultry feed resources and coping mechanisms of challenges in Sidama zone, southern Ethiopia.

[72] Tion MA, anad Adeka I. 2000. The evaluation of cassava root meal as a replacement for maize in broiler diet. Book of proceeding, $25^{\text {th }}$ Annual NSAP Conf. 113-6.

[73] Tsega W and Tamir B. 2009: The effect of increasing levels of dried leaves of sweet potato (Ipomoea batatas) on dry matter intake and body weight gain performance of broiler finisher chickens. Livestock Research for Rural Development. Volume 21, Article \#208.

[74] Tewe O O and Bokanga M. 2001. Research highlights cassava utilization. International Institute of Tropical Agriculture, Ibadan, Nigeria, 2001.

[75] Wondu Mamo, Mehiret Melaku, and Berhan Tamir 2013. Characterization of Urban Poultry Production System in Northern Gondar, Amhara Regional State, Ethiopia Agriculture and Biology Journal of North America.

[76] Yenesew, A., Agraw, A., Yihenew, G., and Dessalegn, M. 2015. Poultry Production Manual. Bahir Dar University Capacity Building for Scaling up of Evidence Best Practices in Agricultural Production in Ethiopia (BDUCASCAPE) Working Paper 14, p: 17. 